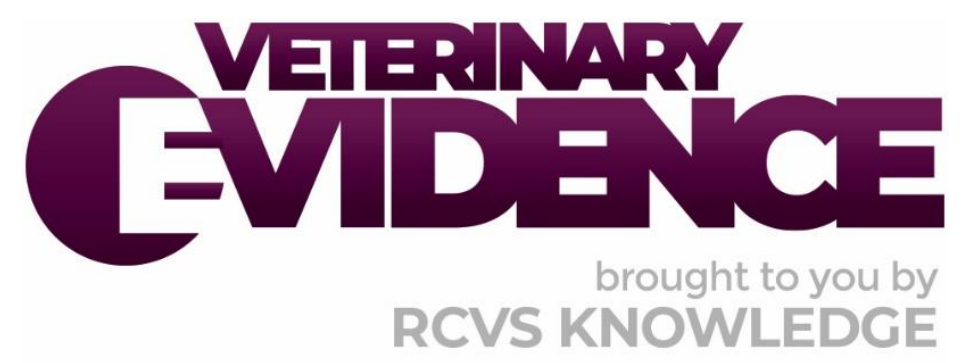

\title{
Is There Any Evidence to Support the Use of Garlic as a Wormer for Dogs and Cats in the UK?
}

\author{
A Knowledge Summary by \\ Louise Buckley PhD, RVN ${ }^{1^{*}}$ \\ ${ }^{1}$ The Royal (Dick) School of Veterinary Studies, University of Edinburgh
${ }^{*}$ Corresponding Author (louise.buckley@ed.ac.uk)
}

ISSN: 2396-9776

Published: 29 May 2019

in: Vol 4, Issue 2

DOI: http://dx.doi.org/10.18849/ve.v4i2.163

Reviewed by: Virginia Fajt (DVM, PhD, DACVCP) and William

Chandler (BVetMed, MRCVS)

Next Review Date: 20 Feb 2021 
KNOWLEDGE SUMMARY

\section{PICO question}

In dogs and cats, is the oral administration of garlic, compared to no treatment, efficacious at preventing or reducing the intestinal worm burden (species found in the UK)?

\section{Clinical bottom line}

No studies were identified that investigated the efficacy of garlic at preventing intestinal worm burden. Garlic reduced egg and/or larvae counts in the worm species studied. However, where measured, egg and larvae count rapidly ( 2 days) returned to pretreatment levels once dietary garlic was discontinued. None of the studies included adulticidal action as an outcome measure. In the absence of research to demonstrate high levels of adulticidal action against a range of intestinal wormers at therapeutic, non-toxic levels in cats and dogs, clients should be advised that garlic has not been demonstrated to be an effective anthelmintic (either for multiple or single species use) for use in dogs and cats either to prevent or to treat an intestinal worm burden.

\section{Clinical Scenario}

The veterinary nurse is reading through the worming advice being given in a Facebook group that encourages a natural approach to preventative medicine in dogs and cats. She notices that garlic is being recommended quite frequently by some pet owners as an alternative to a conventional anthelmintic and wonders what the evidence base is for this recommendation. She notes that some owners are recommending its routine use to prevent dogs or cats becoming parasitised and others are recommending it for dogs or cats known to have an intestinal worm burden so she includes both aspects in her PICO.

\section{The evidence}

No papers were identified that addressed the use of garlic to prevent dogs and/or cats becoming parasitised by intestinal worm species. Three papers were identified that either fully (Bastidas, 1969; Ronagh et al. 2015) or partially (Andrei et al., 2011) addressed the intestinal worm reduction aspect of the PICO. Two of the studies focused on dogs (Bastidas, 1969; Andrei et al., 2011) and one of the studies focused on cats (Ronagh et al., 2015). Not all species of intestinal worm known to parasitise cats and/or dogs in the UK were represented, with tapeworm species being the notable exception. All three studies were clinical trials that either used the animal as its own control (Andrei et al., 2011, Bastidas, 1969) or allocated the animals to separate treatment groups (Ronagh et al., 2015). Random allocation of the latter was not reported. Despite being clinical trials, all three studies are very limited with poor data handling and insufficient reporting of the methodology and/or results.

The Andrei et al. (2011) study used the garlic in conjunction with other herbs so any potential anthelmintic effect of garlic is totally confounded with the other components $(n=6$, plus water) of the tincture and pumpkin oil preparation used. However, this tincture was associated with a greater than $90 \%$ reduction in eggs per gram of faeces for all species (Toxocara canis, Ancylostoma spp., Trichocephalus spp.), with similar findings across both populations (shelter dogs: $n=37$, owned dogs: $n=10)$ ) studied. Bastidas (1969), with a sample size of one, found that larvae count of Ancylostoma Caninum decreased during daily dosing with garlic, but eggs per gram of faeces was only slightly reduced. Rapid recovery to pre-dosing levels ( 2 days) was observed 
following treatment cessation. Finally, Ronagh et al. (2015) found that cats dosed with garlic $(n=5)$ showed a numerical reduction in Toxocara cati eggs on a faecal egg count and a numerical reduction in fecundity rate (number of eggs produced by a female adult Toxocara cati worm). No such reduction in either parameter was observed for Control cats $(n=5)$. None of the studies directly studied the effect of garlic as an adulticide and this remained an important practical limitation in the use of these findings.

\section{Summary of the evidence}

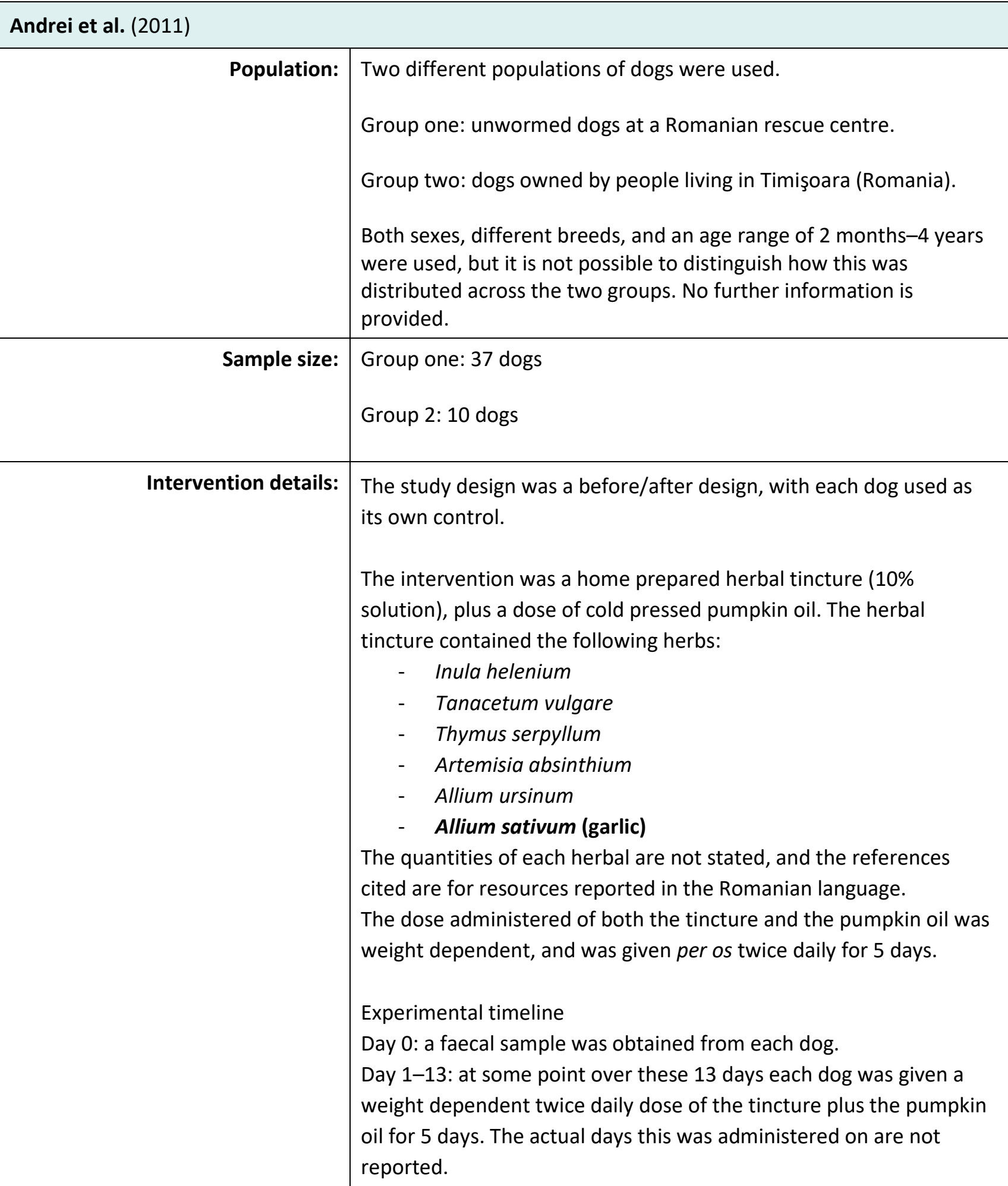




\begin{tabular}{|c|c|}
\hline & $\begin{array}{l}\text { Day 14: a faecal sample was obtained from each dog. } \\
\text { The Willis and McMaster coproscopic method (no reference } \\
\text { provided by the authors) was used to undertake the egg count. }\end{array}$ \\
\hline Study design: & Non-randomised controlled trial (before/after design) \\
\hline Outcome studied: & $\begin{array}{l}\text { Worm eggs per gram of faeces, split down by species/class. Samples } \\
\text { taken before (day } 0 \text { ) and after (day 14) the intervention was applied. } \\
\text { A percentage effectiveness score was then calculated: } \\
\text { Effectiveness (\%) = ((EPG day 0 - EPG day 14) } \div \text { EPG day } 0 \text { ) X } 100 \\
\text { EPG = Eggs per gram }\end{array}$ \\
\hline $\begin{array}{l}\text { Main findings: } \\
\text { (relevant to PICO question): }\end{array}$ & $\begin{array}{l}\text { In summary, for both groups of dogs, the egg count of the three } \\
\text { species present was considerably lower following the intervention. } \\
\text { The following values show the mean } \pm \text { standard error of the mean, } \\
\text { associated with each group/day/species. Please note the authors do } \\
\text { not conduct analytical statistics so there are no p values. They do } \\
\text { report a confidence level of } 95 \% \text { but then appear' to report the } \\
\text { confidence interval as a range, rather than as lower limit and higher } \\
\text { limit. } \\
\text { Group 1: } \\
\text { Toxocara canis: } \\
\text { - Day 0: } 1180.40 \pm 131.19 \\
\text { - } \quad \text { Day 14: } 121.70 \pm 28.61 \\
\text { - } \quad \text { Effectiveness: } 92.55 \% \\
\text { Ancyclostoma spp.: } \\
\text { - Day 0: } 1212.96 \pm 121.41 \\
\text { - } \quad \text { Day 14: } 131.40 \pm 28.39 \\
\text { - Effectiveness: } 91.87 \% \\
\text { Trichocephalus spp.: } \\
\text { - Day 0: } 1011.54 \pm 211.01 \\
\text { - Day 14: } 123.00 \pm 43.34 \\
\text { - } \quad \text { Effectiveness: } 91.34 \% \\
\text { Group 2: } \\
\text { Toxocara canis: } \\
\text { - Day 0: } 800.00 \pm 117.2 \\
\text { - Day 14: } 50.00 \pm 20.41 \\
\text { - Effectiveness: } 93.86 \% \\
\text { Ancyclostoma spp.: } \\
\text { - Day 0: } 810.00 \pm 182.62 \\
\text { - Day 14: } 70.00 \pm 30.00 \\
\text { - Effectiveness: } 92.57 \%\end{array}$ \\
\hline
\end{tabular}




\begin{tabular}{|c|c|}
\hline & $\begin{array}{l}\text { Trichocephalus spp.: } \\
\quad \text { - } \quad \text { Day 0: } 508.30 \pm 83.08 \\
\text { - } \quad \text { Day 14: } 50.00 \pm 18.26 \\
\text { - } \quad \text { Effectiveness: } 93.82 \% \\
\text { 'The interpretation made by the author of this Knowledge Summary. }\end{array}$ \\
\hline Limitations: & $\begin{array}{l}\text { - Inadequate reporting of the scientific method (lacks detail, } \\
\text { not reproducible given the level of detail reported) } \\
\text { - No information regarding the quantity of herbs present in a } \\
\text { standardised dose of the tincture } \\
\text { - No information as to whether the scientists involved in this } \\
\text { study were blinded } \\
\text { - } \quad \text { Data handling is poor: effect sizes calculated for values that } \\
\text { are meaningless, confidence intervals are reported and } \\
\text { labeled incorrectly } \\
\text { - The author uses parametric measures of central tendency } \\
\text { and variation but does not report assessing the distribution } \\
\text { of the data and no skew value is reported } \\
\text { - Although the tincture appears to have a marked effect on } \\
\text { worm burden in dogs it is impossible to quantify the effect, } \\
\text { if any, of the addition of garlic to this preparation } \\
\text { - The sample size for treatment group two is small }\end{array}$ \\
\hline \multicolumn{2}{|l|}{ Bastidas (1969) } \\
\hline Population: & $\begin{array}{l}\text { A dog weighing } 10 \mathrm{~kg} \text { and naturally infected with Ancylostoma } \\
\text { caninum } \\
\text { No further information is available about the dog }\end{array}$ \\
\hline Sample size: & One \\
\hline Intervention details: & $\begin{array}{l}\text { The intervention was the addition of garlic to the dog's diet (ground } \\
\text { meat, once daily). The dose varied daily (see below). } \\
\text { Experimental time line: } \\
\text { Day 1-5: Before phase. Dog was fed ground meat only. } \\
\text { Day 6-10: During phase. Dog was fed ground meat plus garlic. } \\
\text { Day 11-12: After phase. Dog was fed ground meat only. } \\
\text { A faecal sample was collected on all } 12 \text { days, and a daily egg count (4 } \\
\text { replicates, } 50 \text { mg samples) undertaken using the Kato method } \\
\text { (Martin and Beaver, 1968), and a culture (five replicates, } 300 \text { mg } \\
\text { samples) per day were made and allowed to stand for } 10 \text { days (in a } \\
\text { darkened room, at an ambient temperature of } 21-23^{\circ} \mathrm{C} \text { ). The larvae } \\
\text { were then killed using iodine and counted. }\end{array}$ \\
\hline
\end{tabular}




\begin{tabular}{|c|c|}
\hline & $\begin{array}{l}\text { The quantity of garlic fed/ingested was: } \\
\begin{aligned} \text { - } & \text { Day 6: } 6.7 \mathrm{~g} \\
\text { - } & \text { Day 7: } 8.7 \mathrm{~g} \\
\text { - } & \text { Day } 8: 10.1 \mathrm{~g} \\
\text { - } & \text { Day } 9: 10.4 \mathrm{~g} \\
\text { - } & \text { Day } 10: 10.0 \mathrm{~g}\end{aligned}\end{array}$ \\
\hline Study design: & $\begin{array}{l}\text { Non-randomised controlled trial (before intervention/during } \\
\text { intervention/after intervention) }\end{array}$ \\
\hline Outcome studied: & $\begin{array}{l}\text { There were two outcome measures: } \\
\text { 1. Daily mean egg count (eggs/smear) } \\
\text { 2. Daily mean larvae count (larvae/culture) }\end{array}$ \\
\hline \multirow[t]{5}{*}{$\begin{array}{l}\text { Main findings: } \\
\text { (relevant to PICO question): }\end{array}$} & $\begin{array}{l}\text { The author of the research paper reports only raw daily values in a } \\
\text { table. With a sample size of one, there are no analytical statistics. } \\
\text { To aid visualisation of the results, these raw values have been } \\
\text { reported using line graphs created by the author of this Knowledge } \\
\text { Summary. }\end{array}$ \\
\hline & $\begin{array}{l}250 \\
\text { Day } 1 \text { Day } 2 \text { Day } 3 \text { Day } 4 \text { Day } 5 \text { Day } 6 \text { Day } 7 \text { Day } 8 \text { Day } 9 \text { Day } 10 \text { Day } 11 \text { Day } 12 \\
\text { Day of trial }\end{array}$ \\
\hline & $\begin{array}{l}\text { Figure 1: Mean daily egg count. } \mathrm{Nb} \text {. before phase/treatment (day 1- } \\
\text { 5); during phase/treatment (day 6-10); after phase/treatment (day } \\
11-12 \text { ) }\end{array}$ \\
\hline & $\begin{array}{ll}\text { Day } 1 \text { Day } 2 \text { Day } 3 \text { Day } 4 \text { Day } 5 \text { Day } 6 \text { Day } 7 \text { Day } 8 \text { Day } 9 \text { Day } 10 \text { Day } 11 \text { Day } 12 \\
\text { Day of trial }\end{array}$ \\
\hline & $\begin{array}{l}\text { Figure 2: Mean daily larvae count. Nb. before phase/treatment (day } \\
1-5 \text { ); during phase/treatment (day 6-10); after phase/treatment }\end{array}$ \\
\hline
\end{tabular}




\begin{tabular}{|c|c|}
\hline & $\begin{array}{l}\text { (day 11-12) } \\
\text { The author of this Knowledge Summary also undertook the following } \\
\text { analysis on the data reported in the original paper: } \\
\text { Using the formula reported in the Andrei et al. (2011) study, the } \\
\text { percentage of effectiveness was calculated. The mean value before } \\
\text { feeding garlic (day 1-5) was used as the baseline measurement (EPG } \\
\text { day 0), and day } 10 \text { (last day that garlic was fed) as the comparator } \\
\text { (EPG day } 10) \text {. The findings were as follows: } \\
\quad \quad \text { Effectiveness at reducing egg count by day } 10: 14.75 \% \\
\quad \text { effective } \\
\quad \text { Effectiveness at reducing larvae count by day } 10: 81.77 \% \\
\text { effective } 2 \\
\begin{array}{l}14.75 \%=((342.7-296) / 342.7) \times 100 \% \\
281.77 \%=((927.2) / 169) / 927.2) \times 100 \%\end{array}\end{array}$ \\
\hline Limitations: & $\begin{array}{l}\text { - There was a sample size of one } \\
\text { - There is no evidence that blinding was undertaken so the } \\
\text { person handling the faecal sample was potentially aware of } \\
\text { whether the sample corresponded to days on which garlic } \\
\text { was administered } \\
\text { - The dose of garlic was not standardised per day (it is not } \\
\text { clear whether this is because the quantity offered was } \\
\text { different each day, or the quantity voluntarily consumed } \\
\text { was different despite offering a fixed amount) } \\
\text { - The study findings could have been strengthened by a } \\
\text { repeated measures design on this one subject, to help rule } \\
\text { out stochastic or alternative explanations for the findings } \\
\text { - Limited data handling }\end{array}$ \\
\hline \multicolumn{2}{|l|}{ Ronagh et al. (2015) } \\
\hline Population: & $\begin{array}{l}\text { Stray domestic shorthair female cats (weighing circa } 3 \mathrm{~kg} \text { ), captured } \\
\text { from the streets of Tehran and naturally infected with Toxocara cati } \\
\text { roundworms (based on faecal egg counts). }\end{array}$ \\
\hline Sample size: & $\begin{array}{l}25 \text { cats (five per treatment group), drawn from a wider trapped } \\
\text { sample of } 100 \text { cats. The } 25 \text { cats with the heaviest worm burden were } \\
\text { selected from this larger sample. }\end{array}$ \\
\hline Intervention details: & $\begin{array}{l}\text { Cats were allocated to one of five treatment groups: } \\
\text { 1. Control (no treatment) } \\
\text { 2. Garlic (fed one } 1.25 \mathrm{~g} \text { garlic tablet daily) } \\
\text { 3. Black seed (fed } 12 \mathrm{~g} \text { of black seed powder daily) } \\
\text { 4. Pumpkin (fed } 3 \mathrm{~g} \text { of pumpkin seed powder daily) } \\
\text { 5. Cloves (fed } 6 \mathrm{~g} \text { of clove powder daily) } \\
\text { Cats were trapped, housed separately, and given } 3 \text { days to } \\
\text { acclimatise to their environment before the treatments were }\end{array}$ \\
\hline
\end{tabular}




\begin{tabular}{|c|c|}
\hline & $\begin{array}{l}\text { applied. } \\
\text { Experimental timeline: } \\
\text { 1. Day } 0 \text { (prior to treatment): faeces were collected, and stored } \\
\text { in a } 10 \% \text { formalin buffer solution to prevent decay. An egg } \\
\text { count was performed at some point subsequent to this. } \\
\text { 2. Day 7: cats were fed a standard feed ration (not defined in } \\
\text { more detail by the authors), either without a supplement } \\
\text { (Control group) or with a supplement (experimental } \\
\text { treatment groups). The supplement given is outlined in the } \\
\text { treatment group description above. } \\
\text { 3. days after treatments were applied (not clear whether this } \\
\text { is } 7 \text { days after the start or end of the supplement phase): } \\
\text { faeces were collected, and stored in a } 10 \% \text { formalin buffer } \\
\text { solution to prevent decay. An egg count was performed } \\
\text { (formalin-ether sediment method, no reference provided by } \\
\text { the authors) at some point subsequent to this. } \\
\text { Cats were then euthanised, and the stomach and intestines } \\
\text { removed and preserved in 10\% formalin. Sections of } \\
\text { stomach, duodenum, jejunum and ileum were then stained } \\
\text { (haematoxylin and eosin), and examined microscopically for } \\
\text { damage). The number of intestinal adult female Toxocara } \\
\text { cati worms was counted. }\end{array}$ \\
\hline Study design: & Controlled trial (not clear if randomised or nonrandomised) \\
\hline Outcome studied: & $\begin{array}{l}\text { Two outcome measures were relevant to the PICO: } \\
\text { 1. Faecal egg count (Toxocara cati eggs) } \\
\text { 2. Fecundity rate (Toxocara cati worms) } \\
\text { The fecundity rate was calculated using the following equation: } \\
\text { Fecundity rate = EPG } \div \text { Number of female adult worms } \\
\text { EPG = eggs per gram }\end{array}$ \\
\hline $\begin{array}{l}\text { Main findings: } \\
\text { (relevant to PICO question): }\end{array}$ & 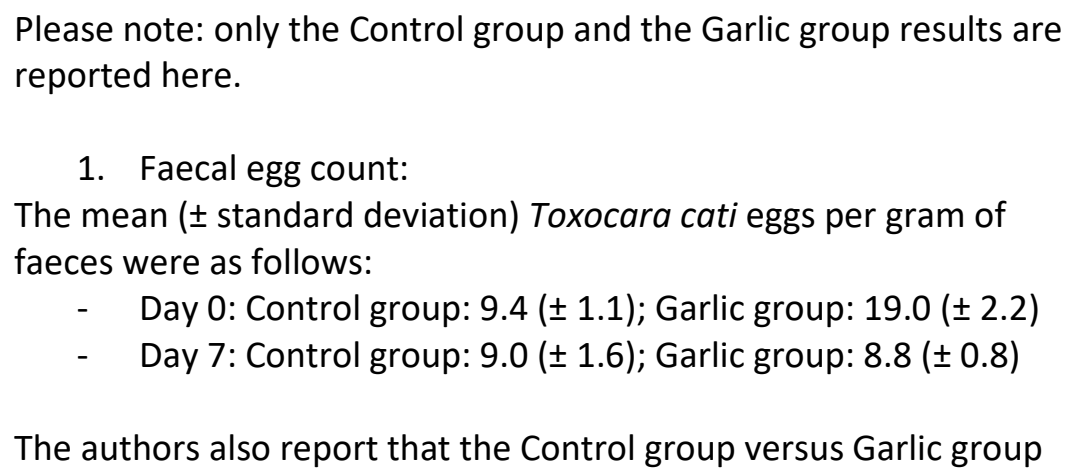 \\
\hline
\end{tabular}




\begin{tabular}{|c|c|c|c|c|}
\hline & \multicolumn{4}{|c|}{$\begin{array}{l}\text { was significantly different ( } T \text {-test, } P=0.003 \text { ). } \\
\text { Nb. They do not make clear what data this T-test was performed } \\
\text { with (the raw data for day } 0 \text { or day } 7 \text {, or a comparison between } \\
\text { groups after calculating the difference in EPG between day } 0 \text { and } \\
\text { day } 7 \text { for each individual cat. No other statistical analysis is } \\
\text { performed (e.g. within treatment differences) on this data. } \\
\text { 2. Fecundity rate: } \\
\text { The authors report only raw data (individual animals) for this data. } \\
\text { The raw data can be seen in table } 1 \text { below. } \\
\text { Table 1: A comparison of the fecundity rate for cats in the control } \\
\text { and garlic treatment groups }\end{array}$} \\
\hline & $\begin{array}{l}\text { Treatment } \\
\text { group }\end{array}$ & Animal no. & $\begin{array}{l}\text { Day 0: } \\
\text { fecundity rate }\end{array}$ & $\begin{array}{l}\text { Day } 7 \text { : } \\
\text { fecundity rate }\end{array}$ \\
\hline & \multirow{5}{*}{ Control } & 1 & 5.5 & 5.5 \\
\hline & & 2 & 5 & 5 \\
\hline & & 3 & 9 & 9 \\
\hline & & 4 & 4.5 & 4 \\
\hline & & 5 & 8 & 7 \\
\hline & \multirow{5}{*}{ Garlic } & 1 & 6.66 & 3 \\
\hline & & 2 & 11 & 5 \\
\hline & & 3 & 9 & 4.5 \\
\hline & & 4 & 9.5 & 4 \\
\hline & & 5 & 16 & 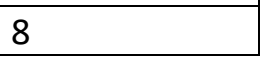 \\
\hline & \multicolumn{4}{|c|}{$\begin{array}{l}\text { Descriptive statistics (below) have been performed on this data set } \\
\text { by the Knowledge Summary author using the same parameters used } \\
\text { by the paper authors in the first outcome measure. Data distribution } \\
\text { or skewness has not been evaluated. } \\
\text { The mean ( } \pm \text { standard deviation) fecundity rate was as follows: } \\
\quad-\quad \text { Day 0: Control group: } 6.4( \pm 2.0) \text {; Garlic group: } 10.4( \pm 3.5) \\
\quad \text { - Day 7: Control group: } 6.1( \pm 1.9) \text {; Garlic group: } 4.9( \pm 1.9)\end{array}$} \\
\hline Limitations: & \multicolumn{4}{|c|}{$\begin{array}{l}\text { - The authors do not report how they allocated the cats to the } \\
\text { different treatment groups so it is not known whether cats } \\
\text { were randomly allocated to receive the different } \\
\text { treatments. } \\
\text { - } \quad \text { There is no evidence that the researchers or any other } \\
\text { personnel involved in the study (if any) were blinded as to } \\
\text { the treatments when collecting/analysing data. } \\
\text { - } \quad \text { Insufficient experimental detail (in both the methods and } \\
\text { results sections) is available to fully understand or interpret } \\
\text { the study findings. } \\
\text { - There is insufficient detail in the methods to fully appraise } \\
\text { scientific rigour (e.g. in relation to egg count methodology, } \\
\text { use of duplicate samples, etc.) } \\
\text { - Statistical analysis is limited and it is unclear what the p }\end{array}$} \\
\hline
\end{tabular}




\begin{tabular}{|l|l|}
\hline value reported relates to. The authors appear to have \\
compared treatment groups before treatment application \\
and not after. However it is possible that they have used \\
'within treatment differences in egg count between day 0 \\
and day 7' data, and then conducted a between treatment \\
group T-test on the 'differences' data. This would allow \\
them to undertake one statistic test to compare between \\
treatment groups, while also handling the data in a manner \\
that would increase the likelihood of finding significant \\
differences where there is a lot of variation between dogs in \\
terms numbers of eggs present in faeces at either time \\
point. The authors do not tell us though that they do this \\
and this lack of detail is a study failing. \\
The authors do not justify their use of parametric statistical \\
analysis or choice of measure of central tendency. \\
The sample size per treatment group is very small and does \\
not appear to be based on a power calculation or other \\
approach to determine an appropriate sample size. \\
The treatment groups differed in mean number of eggs per \\
gram of faeces (the Garlic group had approximately double \\
the number of eggs compared to the Control group) on day \\
o (prior to treatment application). Likewise, the fecundity \\
rate of the Garlic group was higher than the Control group at \\
the start of the study (day 0). \\
The authors report that garlic reduced the number of female \\
adult worms and refer the reader to table 2 in \\
demonstration of this. However, table 2 refers to fecundity \\
rate (not the number of adult female worms) and this value \\
cannot be used to quantify number of adult female worms \\
present using the information provided. The number of \\
adult female worms was not listed as a planned outcome \\
measure, and is not reported anywhere else in the paper. \\
\end{tabular}

\section{Appraisal, application and reflection}

Plant-based anthelmentics have been suggested as a potential alternative to overcome increasing resistance to conventional anthelmentics (French, 2018). The use of garlic as a traditional anthelmintic for dogs with intestinal worms has been reported ( $\mathrm{n}=1$ interviewee) in a study exploring central-southern Italy's ethnoveterinary practices (Guarrera et al., 2008), and more widely elsewhere in pigs (Lans et al., 2007; Bartha et al., 2015) and ruminants (Lans et al., 2007; Bullitta et al., 2018). Thus, the promotion of garlic as an anthelmintic in dogs and cats is probably derived from traditional ethnobotanical medical practices. More recently, there has been some growth in scientific interest in its potential anthelmintic properties in a range of mammalian and avian species. Extracts from garlic bulbs shown to have in vivo (e.g. Palacious-Landin et al., 2015, but see e.g. Worku, 2009; Velkers et al., 2011) and/or in vitro (e.g. Palacious-Landin et al., 2015; Orengo et al., 2016; Tavassoli et al., 2018) efficacy (differing stages of the life cycle, dependent on the study) against various species of helminth. This includes in vitro activity against some species (Toxocara canis, Ancylostoma caninum) that infest dogs (Orengo et al., 2016). Consequently, scientific and veterinary growth in its interest in a wormer for dogs and cats may be likely to develop over time.

No English language papers were identified that addressed the prevention aspect of the PICO. Three papers were identified that either fully (Bastidas, 1969; Ronagh et al., 2015) or partially (Andrei et al., 2011) addressed the treatment aspect of the PICO. Two of the studies focused on dogs (Bastidas, 1969; Andrei et 
al., 2011) and one of the studies focused on cats (Ronagh et al., 2015). A further abstract (Bekirov et al., 1979) that examined the use of garlic (in conjunction with other ingredients) as a canine anthelmintic effective against Echinococcus or Taenia hydatigena was excluded as the main paper was in Russian but reported $92-94.8 \%$ and $100 \%$ efficacy respectively against each species. The relative lack of studies that addressed the PICO also meant that some of the intestinal worms known to affect dogs and cats in the UK did not have any evidence available to address the use of garlic as an anthelmintic for that species. Studies focusing on tapeworm species were notably absent, with the exception of the Bekirov study, which combined garlic with several other products thereby confounding interpretation of the efficacy of garlic per se as an anthelmintic. Thus, any positive anthelmintic effects at the level of the individual species may still limit clinical use to the practitioner or owner when seeking an anthelmintic effective against a broad range of intestinal worms.

All three studies included in this Knowledge Summary were clinical trials, which either used the animal as its own control (Andrei et al., 2011, Bastidas, 1969) or allocated the animals to separate treatment groups (Ronagh et al., 2015). However, despite being clinical trials, all of the studies showed clear limitations in terms of methodological approach and/or study methodology reporting and/or results reporting and highlight the importance of not using the evidence pyramid (see: O'Connor, 2017 for a discussion on the limitations to the evidence pyramid) in isolation when evaluating the relative quality of a study. Furthermore, the outcome measures used by each of the studies used are unlikely to address the clinical need of veterinary practitioners or clients seeking an anthelmintic that will kill intestinal worms present at the point of dosing the dog or cat.

In the Andrei et al. (2011) study a 90\% reduction in eggs per gram of faeces for all species (Toxocara canis, Ancylostoma spp, Trichocephalus spp.) following a twice daily weight dependent dose of their worming preparation (tincture and pumpkin oil). Similar results were obtained for both populations (shelter dogs: $\mathrm{n}=$ 37, owned dogs: $n=10)$ ) studied. However, this worming preparation used the garlic in conjunction with other herbs so any potential anthelmintic effect of garlic is totally confounded with the other components ( $\mathrm{n}$ $=6$, plus water) of the tincture and pumpkin oil preparation used. Thus, it is impossible to quantify the relative contribution (positive, negative, additive, synergistic, or no effect at all) of garlic to these findings. In defence of the authors, this study was designed to test the efficacy of this worming preparation rather than to investigate the efficacy of garlic in isolation as an anthelmintic. However, this study is also problematic in terms of its scientific quality, with authors failing to report tincture composition in sufficient detail, with no detail available on the quantity of each herb added to the tincture preparation. Dosing standardisation was achieved through product dosing based on the weight of the dog, but this is only described in terms of quantity of the tincture plus pumpkin oil supplied. Despite the most impressive sample size (relative to the other two studies reported here), the authors do not perform analytical statistics on their findings, and while they describe reporting the confidence intervals (which can be used in preference to $p$ values), they appear to be reporting this as one value rather than as an upper and lower limit which limits its value in interpreting the data. However, the descriptive statistics do suggest that the before and after treatment faecal egg counts would be significantly different across all three of the worm species studied (and the direction of the effect is similar for both shelter and owned dogs) should a suitable analytical test be performed. Despite this, the study suffers from another key issue when considering the clinical application of this tincture, and that is that the outcome measure assessed did not include either a direct or indirect (proxy) measurement of the effect of the preparation on adult worm mortality and/or long-term fecundity. The study finished immediately after the end of the tincture and pumpkin oil dosing period. Thus, all that is known is that this worming preparation had effects on egg production during the period of dosing, without anything to indicate the possible reason for this reduction. This is a clinically important issue that is of relevance to any anthelmintic product selection, and represents a major study limitation within the context of any clinician considering using this worming preparation in preference to any product with known adulticidal efficacy.

The second of the studies evaluated (Bastidas, 1969) was included as a clinical trial based on its study methodology (before, during, after treatment) allowing it to meet the inclusion criteria but it had a sample size of one dog, and with each study phase undertaken only once, findings were potentially explicable, either partially or fully, by other undefined or unreported effects. This should be borne in mind when considering the reported findings. This study found that larvae count of Ancylostoma caninum decreased during daily 
dosing with garlic (non-standardised dose), but eggs per gram of faeces remained similar following a five-day dosing period. Application of the Andrei et al. (2011) equation for evaluating anthelmintic efficacy to Bastidas' (1969) raw data indicated that efficacy at reducing egg count after 5 days of garlic treatment was only $14.75 \%$. This was much lower than the Andrei et al. (2011) study, and suggests that other components of the Andrei et al. study's worming preparation may have explained the increased efficacy at reducing egg count identified in that study. However, there are other differences in the study methodology and lack of detail regarding the tincture preparation mean that meaningful comparisons are difficult to draw. Garlic appeared more effective at reducing larvae count and was $81.77 \%$ effective at reducing larvae count by day 5 (the last day) of treatment. However, it is important to note that this effect was very short lived and mean larvae count increased rapidly ( 1 day) following discontinuation of the garlic and returned to approximately pretreatment levels only 2 days after discontinuation of the garlic. Again, while the presence of viable adult female worms was not an outcome measure of this study, these post-treatment changes in larvae count suggest that the addition of garlic to the diet at this dosage and dosing period did not affect adult female worm mortality or longer-term fecundity rates.

Finally, Ronagh et al. (2015) found that cats dosed with garlic $(n=5)$ showed a numerical reduction in Toxocara cati eggs on a faecal egg count and a numerical reduction in fecundity rate (number of eggs produced by a female adult Toxocara cati worm). No such reduction in either parameter was observed for Control cats $(n=5)$. However, this study euthanised the cats at the end of the study (to assess fecundity rate and gastrointestinal damage to the mucosa) and did not measure faecal egg counts for a few days posttreatment cessation. Thus, while it is known that egg counts were lower, and this reduction was probably due to a reduction in the number of eggs produced by each viable female, it is not known whether any inhibitory effect of the garlic is temporary (i.e. females will increase egg production when the garlic is discontinued) or whether it is more permanent (e.g. through increased morbidity/mortality rates of adult female worms). In the light of the Bastidas (1969) study findings this is an important consideration. This study did count the number of adult female worms present within the intestines at the point of euthanasia of both the Control group and the Garlic group but does not report this information. However, the authors do not report how the cats were allocated to their respective treatment groups. Frustratingly, the pretreatment faecal egg count demonstrates that the Control cats had a lower mean ( \pm standard deviation) faecal egg count $(9.4 \pm 1.1$ ) and fecundity rate $(6.4 \pm 2.0)$ than the Garlic group (egg count: $19.0 \pm 2.0$; fecundity rate: $10.4 \pm 3.5$ ), with important implications for data handling, analysis and interpretation. The authors' report a significant effect of treatment group (Garlic versus Control) but fail to report what data was analysed to obtain this probability value, and its value to the data interpretation is thereby questionable. With better management of subject allocation to the treatment groups (for example by using faecal egg counts to rank cats according to worm burden severity and then allocating to treatments using a randomised block approach) this study could have been strengthened. It is not clear why this was not undertaken as the authors originally trapped 100 cats, and retained the 25 most Toxocara cati parasitised cats to use in this study, so this limitation could have been addressed at the study outset.

In summary, based on the limited and relatively poor quality studies available to address the PICO, garlic may have a temporary inhibitory action on larvae and/or egg production of the intestinal worm species studied but none of the studies directly investigated the effect of garlic on adult worm mortality or viability. However, where a proxy measure was used (egg/larvae production after treatment cessation) this suggested that garlic did not have adulticidal action against Ancyclostoma caninum. In the absence of research to demonstrate high levels of adulticidal action against a range of intestinal wormers at therapeutic, non-toxic levels in cats and dogs, clients should be advised that garlic is not proven as an effective anthelmintic (either against multiple species or a single species) for use in dogs and cats with to prevent, or to treat, an intestinal worm burden. 


\begin{tabular}{|c|c|}
\hline $\begin{array}{r}\text { Databases searched and dates } \\
\text { covered: }\end{array}$ & $\begin{array}{l}\text { Pubmed, accessed via the NCBI website (01/01/1900 - 20/02/2019); } \\
\text { Web of Science (1990-20/02/2019) }\end{array}$ \\
\hline & $\begin{array}{l}\text { Pubmed \& Web of Science search: } \\
\text { (dog OR dogs OR canine OR canid OR canis OR bitch OR bitches OR } \\
\text { pup OR puppy OR puppies OR cat OR cats OR feline OR felid OR } \\
\text { kitten OR kittens) AND (garlic OR "allium sativum") AND (worm OR } \\
\text { tapeworm OR tape-worm OR "tape worm" OR roundworm OR } \\
\text { round-worm OR “round worm" OR hookworm OR hook-worm OR } \\
\text { "hook worm" OR whipworm OR whip-worm OR “whip worm" OR } \\
\text { flatworm OR "flat worm" OR flat-worm OR endoparasite OR endo- } \\
\text { parasite OR parasite OR parasitic OR anthelmintic OR ascarid OR } \\
\text { ascaris OR larvae OR toxocara OR toxascaris OR ancylostoma OR } \\
\text { trichuris OR uncinaria OR Dipylidium OR Taenia OR echinococcus OR } \\
\text { cestode OR cestodes OR nematode OR nematodes OR Trematode } \\
\text { OR Trematodes OR Fluke OR Flukes OR Nanophytus OR heterophyes } \\
\text { OR cryptocotyle OR apophallus OR alaria) }\end{array}$ \\
\hline
\end{tabular}

CAB Abstract search:

1. (dog or dogs or canine or canid or canis or bitch or bitches or pup or puppy or puppies or cat or cats or feline or felid or kitten or kittens).mp. [mp=abstract, title, original title, broad terms, heading words, identifiers, cabicodes]

2. (garlic or allium sativum).mp. [mp=abstract, title, original title, broad terms, heading words, identifiers, cabicodes]

3. (worm or tapeworm or tape-worm or tape worm or roundworm or round-worm or round worm or hookworm or hook-worm or hook worm or whipworm or whip-worm or whip worm or flatworm or flat worm or flat-worm or endoparasite or endo-parasite or parasite or parasitic or anthelmintic or ascarid or ascaris or larvae or toxocara or toxascaris or ancylostoma or trichuris or uncinaria or Dipylidium or Taenia or echinococcus or cestode or cestodes or nematode or nematodes or Trematode or Trematodes or Fluke or Flukes or Nanophytus or heterophyes or cryptocotyle or apophallus or alaria).mp. [ $\mathrm{mp}=$ abstract, title, original title, broad terms, heading words, identifiers, cabicodes]

4. 1 and 2 and 3
Dates searches performed: 
Exclusion / Inclusion Criteria

Exclusion: Pre-defined exclusion criteria: non-English language, popular press articles, in vitro studies, conference abstracts

Inclusion: Any comparative study in which the effect of garlic on intestinal worms in dogs or cats was studied

\begin{tabular}{|c|c|c|c|c|c|c|}
\hline \multicolumn{7}{|l|}{ Search Outcome } \\
\hline Database & $\begin{array}{l}\text { Number } \\
\text { of } \\
\text { results }\end{array}$ & $\begin{array}{l}\text { Excluded - did } \\
\text { not answer } \\
\text { the PICO } \\
\text { question }\end{array}$ & $\begin{array}{c}\text { Excluded - not } \\
\text { English } \\
\text { language }\end{array}$ & $\begin{array}{l}\text { Excluded - } \\
\text { conference } \\
\text { abstract only }\end{array}$ & $\begin{array}{l}\text { Excluded - } \\
\text { duplicates }\end{array}$ & $\begin{array}{l}\text { Total } \\
\text { relevant } \\
\text { papers }\end{array}$ \\
\hline Pubmed & 8 & 7 & 0 & 0 & 0 & 1 \\
\hline Web of Science & 10 & 0 & 0 & 0 & 0 & 0 \\
\hline CAB Abstracts & 17 & 14 & 1 & 0 & 0 & 2 \\
\hline \multicolumn{6}{|c|}{ Total relevant papers when duplicates removed } & 3 \\
\hline
\end{tabular}

\section{CONFLICT OF INTEREST}

The author declares no conflicts of interest.

\section{REFERENCES}

1. Andrei, S., Ilie, M. S., Mederle, N. \& Darabus, G. (2011) Testing the effectiveness of a plant extract in the therapy on some endoparasites in dogs. Lucrari Stiintifice - Medicina Veterinara, Universitatea de Stiinte Agricole si Medicina Veterinara "Ion Ionescu de la Brad" Iasi, 54(3), pp. 247-254.

2. Bartha, S. G., Quave, C. L., Balogh, L., Papp, N. (2015) Ethnoveterinary practices of Covasna County, Transylvania, Romania. Journal of Ethnobiology and Ethnomedicine 11: 35 [online] Available from: https://ethnobiomed.biomedcentral.com/articles/10.1186/s13002-015-0020-8 (accessed: 16/05/2019) DOI: http://dx.doi.org/10.1186/s13002-015-0020-8

3. Bastidas, G. J. (1969) Effect of ingested garlic on Necator americanus and Ancylostoma caninum. The American Journal of Tropical Medicine and Hygiene, 18(6), pp. 920-923. DOI: http://dx.doi.org/10.4269/ajtmh.1969.18.920

4. Bekirov, R. E., Azimov, Sh. A., Oripov, A. O., \& Dzhumaev, Z. (1979) The efficacy of granules against cestodes in dogs. Veterinariya, Moscow 8, pp. 50-51.

5. Bullitta, S., Re, G. A., Manunta, D. I., \& Oiluzza, G. (2018) Traditional knowledge about plant, animal, 
and mineral-based remedies to treat cattle, pigs, horses, and other domestic animals in the Mediterranean island of Sardinia. Journal of Ethnobiology and Ethnomedicine 14: 50 [online] Available from: https://ethnobiomed.biomedcentral.com/articles/10.1186/s13002-018-0250-7 (accessed: 16/05/2019) DOI: http://dx.doi.org/10.1186/s13002-018-0250-7

6. Buona, F., Pacifico, L., Piantedosi, D., Sgroi, G., Neola, B., Roncoroni, C., Genovese, A., Rufrano, D., \& Veneziano, V. (2019) Preliminary Observations of the Effect of Garlic on Egg Shedding in Horses Naturally Infected by Intestinal Strongyles. Journal of Equine Veterinary Science 72: 79-83. DOI: http://dx.doi.org/10.1016/i.jevs.2018.10.025

7. French, K. E. (2018) Plant-Based Solutions to Global Livestock Anthelmintic Resistance. Ethonobiology Letters 9(2): 110-123. DOI: http://dx.doi.org/10.14237/ebl.9.2.2018.980

8. Guarrera, P. M., Lucchese, F., \& Medori, S. (2008) Ethnophytotherapeutical research in the high Molise region (Central-Southern Italy). Journal of Ethnobiology and Ethnomedicine 4: 7 [online] Available from: https://ethnobiomed.biomedcentral.com/articles/10.1186/1746-4269-4-7 (accessed: 16/05/2019) DOI: http://dx.doi.org/10.1186/1746-4269-4-7

9. Lans, C., Turner, N., Khan, T., Brauer, G., \& Boepple, W. (2007) Ethnoveterinary medicines used for ruminants in British Columbia, Canada. Journal of Ethnobiology and Ethnomedicine 3: 11 [online] Available from: https://ethnobiomed.biomedcentral.com/articles/10.1186/1746-4269-3-11 (accessed: 16/05/2019) DOI: http://dx.doi.org/10.1186/1746-4269-3-11

10. O'Connor, A. (2017) Is the simplicity of the evidence pyramid actually detrimental for understanding evidence? Veterinary Evidence 2(1). DOI: http://dx.doi.org/10.18849/ve.v2i1.100

11. Orengo, K. O., Maitho, T., \& Mbaria, J. 2016. In vitro anthelmintic activity of Allium sativum, Allium cepa and Jatropha curcas against Toxocara canis and Ancylostoma caninum. African Journal of Pharmacy and Pharmacology 10(21): 465-471.

12. Martin, L. K. \& Beaver, P. C. (1968) Evaluation of Kato thick-smear technique for quantitative diagnosis of helminth infections. American Journal of Tropical Medicine and Hygiene 17, pp. 382-391. DOI: http://dx.doi.org/10.4269/ajtmh.1968.17.382

13. Palacious-Landin, J., Mendoza-de Gives, P., Salinas-Sanchez, D. O., Lopez-Arellano, M. E., LiebanoHernadez, E., Hernadez-Velazquez, V. M., \& Valladares-Cisneros, M. G. (2015) In vitro and in vivo nematocidal activity of Allium sativum and Tagetes erecta extracts Against Haemonchus contortus. Turkish Journal of Parasitology 31: 277-282. DOI: http://dx.doi.org/10.5152/tpd.2015.4523

14. Ronagh, K., Gharouni, A., Bahadori, S. R., Zakian, A., Gholami, N., Rezaeian, H. \& Shahraki, M. S. (2015) Effect of Nigella sativa, Allium sativum, Syzgium aromaticum and Cucurbita maxima on Toxocara cati fecal egg count in stray cats. Online Journal of Veterinary Research, 19(5), pp. 325-330.

15. Tavassoli, M., Jalilzadeh-Amin, G,. Fard, V. R. B., \& Esfandiarpour, R. 2018. The in vitro effect of Ferula asafoetida and Allium sativum extracts on Strongylus spp. Annals of Parasitology 64(1): 59-63.

16. Velkers, F. C., Dieho, K., Pecher, F. W. M., Vernooij, J. C. M., van Eck, J. H. H., \&Landman, W. J. M. (2011) Efficacy of allicin from garlic against Ascaridia galli infection in chickens. Poultry Science 90(2): 364-368. DOI: http://dx.doi.org/10.3382/ps.2010-01090

17. Worku, M., Franco, R., \& Baldwin, K. (2009) Efficacy of garlic as an anthelmintic in adult Boer goats. Archives of Biological Sciences 61(1): 135-140. DOI: http://dx.doi.org/10.2298/ABS0901135W 


\section{EVIIDEFeE

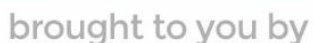 \\ RCVS KNOWLEDGE}

\section{Intellectual Property Rights}

Authors of Knowledge Summaries submitted to RCVS Knowledge for publication will retain copyright in their work, and will be required to grant RCVS Knowledge a non-exclusive license of the rights of copyright in the materials including but not limited to the right to publish, re-

publish, transmit, sell, distribute and otherwise use the materials in all languages and all media throughout the world, and to license or permit others to do so.

\section{Disclaimer}

Knowledge Summaries are a peer-reviewed article type which aims to answer a clinical question based on the best available current evidence. It does not override the responsibility

of the practitioner. Informed decisions should be made by considering such factors as individual clinical expertise and judgement along with patient's circumstances and owners' values. Knowledge Summaries are a resource to help inform and any opinions expressed within the Knowledge Summaries are the author's own and do not necessarily reflect the view of the RCVS Knowledge. Authors are responsible for the accuracy of the content. While the

Editor and Publisher believe that all content herein are in accord with current recommendations and practice at the time of publication, they accept no legal responsibility

for any errors or omissions, and make no warranty, express or implied, with respect to material contained within.

For further information please refer to our Terms of Use.

RCVS Knowledge is the independent charity associated with the Royal College of Veterinary Surgeons (RCVS). Our ambition is to become a global intermediary for evidence based veterinary knowledge by providing access to information

that is of immediate value to practicing veterinary professionals and directly contributes to evidence based clinical decision-making.

\section{https://www.veterinaryevidence.org/}

RCVS Knowledge is a registered Charity No. 230886.

Registered as a Company limited by guarantee in England and Wales No. 598443.

Registered Office: Belgravia House, 62-64 Horseferry Road, London SW1P 2AF

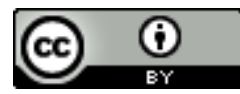

This work is licensed under a Creative Commons Attribution 4.0 International License. 